\title{
Subjectification and intersubjectification in the analysis of the Polish adverb niestety 'unfortunately/ regrettably'
}

\begin{abstract}
The present article aims at summarizing the results of the corpus-based study of the semanto-syntactic behaviour of the emotionally-loaded Polish adverb niestety 'unfortunately/regrettably'. It will be claimed that the different uses of niestety are governed by the processes of subjectification, both at the synchronic and diachronic level. Such a perspective also allows us to explain the intersubjective senses in which this highly grammaticalized adverb is sometimes used in Polish.
\end{abstract}

Key words: subjectification, intersubjectification, emotional attitude, adverbs, modality.

\section{Introduction}

In the present article, the focus is on the Polish lexical item niestety 'unfortunately/regrettably' and the modal meanings that it conveys. While some types of modality, especially those expressed by means of modal auxiliaries, like dynamic, deontic, or epistemic modalities, have received considerable attention from linguists, some other types remain on the margins of this (super)category (see the discussion in Nuyts 2006: 1-9). These include modalities such as evidentiality, volitionality, as well as boulomaic modality, or emotional attitude, as it is more often referred to (see Nuyts 2005, 2006, among others). They are most often expressed by lexical and morphological means (see Nuyts 2005: 14f). For example, in Polish, emotional and valorative meanings can be encoded by means of nouns (see e.g. Krzyżanowski 1992; Milewska 2003) and verbs (see Kozarzewska 1990: 117-151). Szymanek (2010: 206-215), in his account of Polish word-formation, points to the morphological means of expressing evaluation and attitude and discusses devices such as: diminutives, which frequently carry additional, affectionate or pejorative meanings (e.g. pijak 'drunkard' > pijaczek/pijaczyna), or the intensification suffixes, the majority of which is appreciative (e.g. czysty 'clean' > czyściutki 'very clean'). Attitude can be expressed even by functional free morphemes, such as demonstratives (e.g. ten 'this', as in Co ten Olszewski wyprawia to ludzkie 
pojęcie przechodzi 'What Olszewski is doing is just unbelievable') and possessives (e.g. mój 'my', as in Jadę bo muszę tam być, to był mój prezydent 'I'm going because I've got to be there, it was my president') (see Rybarczyk 2015).

Adverbs, next to adjectives, are the lexical means frequently employed for modal expression in many languages (see Nuyts 1994; Hoye 1997; de Haan 2006; Traugott 2012; among others). Importantly, adverbs often express attitudinal senses, i.e. those concerned with the degree of "the commitment of the speaking subject (or another reported person) towards the state of affairs" (Nuyts 2005: 23). The nature of this commitment may be moral, as in the case of deontic modality, "existential", as with epistemic modality, or evaluative, as in the case of emotional attitude. Niestety 'unfortunately/regrettably' exemplifies the last category, as it expresses the dissatisfaction of the speaker and his/her negative attitude towards the described state of affairs.

\section{Niestety and its corpus in the present study}

According to the Etymologiczny słownik jezyka polskiego (Bańkowski 2000), niestety began to be used as an adverb in the sense of na nieszczęście, 'unfortunately' (lit. on.PREP misfortune.ACC) in the $18^{\text {th }}$ century, being occasionally used in this sense since 1597 . According to this source, it emerged gradually and originated from the noun niestoty which, between the 16th and 17th centuries, meant 'biada' 'distress/hardship', as in niestoty mnie 'poor me', a use dating back to 1545.

Grzegorczykowa (see 2008: 65) points out that the "modal particle" niestety and other expressions of emotional attitude in Polish belong to the group of higher-level predicates having a scope over the whole sentence, as in Nasz wspólny przyjaciel lubi, niestety, długo spać przy zasłoniętych zasłonach 'Our mutual friend likes, unfortunately, to sleep long with the curtains drawn'. Other adverbs and adverbials that exemplify this group are expressions of frequency, as well as some temporal and locative expressions (ibid.). ${ }^{1}$

The analysis of the uses of niestety 'unfortunately/regrettably' was conducted on the corpus collected for the sake of a larger study of the adverbial means of expression of boulomaic modality, or attitude, in Polish (see Piórkowska 2011). In the study, the corpora of niestety 'unfortunately/regrettably', na szczęście (lit. on.PREP fortune.ACC) 'fortunately', and szczęśliwie 'happily/fortunately' were obtained through Google search, applied in a random but principled way as suggested by Taylor and Pang (2008). ${ }^{2}$

Qualificational rather than quantificational, the study revealed that the semanto-syntactic behavior of these adverbs is governed by the processes of subjectification (in all three cases) and intersubjectification (occasionally in the case of na szczęście, and quite frequently in the case of niestety).

1 In my work, I use the terms adverb and adverbial interchangeably to refer to niestety 'unfortunately/regrettably', in accordance with the definitions offered in Hoye (1997).

2 Following the methodology of Taylor and Pang (2008), in my study I used the Google search and collected relatively small databases of fifty examples of niestety, na szczęście and szczéśliwie, in each case, with the contexts in which they were used, taking the first ten uses of the items at intervals of one hundred, ignoring repeated hits, as well as hits that included incomplete contexts or contexts with vulgar language. 


\section{Views on subjectification and intersubjectification}

The present study embraces two predominant approaches to subjectification in linguistic theory: Langacker's Cognitive Grammar approach and the approach of Traugott and her collaborators. As for the analysis itself, it employs three factors: (i) fixation of form and autonomy of predication, (ii) fronting and widening of predicational scope, and (iii) weakening of agent control, which were identified and used by Company (2006) in her analysis of Spanish language data.

For Langacker (1989), subjectification is a phenomenon concerned with the degree to which an entity is construed with respect to the speaking subject. It is assumed that meaning cannot be described in purely objective terms. In Langacker's sense, the terms subjectivity and objectivity indicate the roles of the subject and the object of perception. An entity is subjectively or objectively construed in that it functions as the subject or an object of perception, subject and object not to be equated with the grammatical subject and object. Both the speaker (S) and the hearer $(\mathrm{H})$ are conceptualizers, that is subjects of conception and, as such, they typically remain offstage, subjectively construed. For example, in the case of expressions like $d o g$, the roles of $\mathrm{S}$ and $\mathrm{H}$ are limited to those of offstage conceptualizers, external to the scope of the expression (see Langacker 1999: 150). On the other hand, deictic elements like the article in the dog bring the speaker and the hearer into the overall scope as they indicate a degree of specificity of the apprehended entity. According to Langacker, in this particular case, the $\mathrm{S}$ and the $\mathrm{H}$ are still only tacitly referred to, and therefore they remain offstage. They go on stage and are profiled in the case of expressions such as pronouns $I$, you, or we.

Originally, subjectification was understood by Langacker (1991) as a replacement of an objectively described relationship by a subjectively construed one, "inherent in the very process of conception". Langacker (1999) proposes a refined characterization of subjectification which does not assume a replacement of the objective component by the subjective one, but presupposes that the subjective component is "immanent" in the objective conception. It is left behind when the objective basis for the conceptualization fades away (see Langacker 1999:151f).

The objective construal profiles the relationship between the trajector and the landmark, the trajector being typically more active, usually an agent, an experiencer, or a mover (see Langacker 1999: 152). Within a certain processing time, the relationship undergoes "mental scanning" by the conceptualizer $(\mathrm{C})$, with the trajector serving as the access point for the conceptualization. In The child hurried across the street, the child is the trajector of across, and the conceptualizer is confronted with an objectively construed relationship between this trajector and the landmark, the street.

In a more subjective construal the degree of subject control weakens and provides less objective motivation for the relationship to the conceptualizer. In Langacker's terms, the objective motivation for the profiled relationships becomes "attenuated", as in another sense of across in There is a mailbox across the street. It is a case of attenuation because the entity selected as the trajector is static, neither an agent, nor an experiencer or a mover, and only occupies a single position with respect to the landmark (see 1999: 153). However, the configuration evokes at least some potential movement by a generalized or generic individual for whom the location 'across the street' is the 
potential goal. Eventually, in cases of full subjectification, the relationship between the trajector and the landmark exists only due to the conceptualizer's mental activity; the objective basis for it disappears. In Last night there was a fire across the street, the conception of physical motion is "entirely absent, leaving only subjective motion by the conceptualizer, who mentally traces along the path in order to specify the trajector's location" (Langacker 1999: 155). It is in this sense that Langacker speaks of the subjective relationship being "immanent in the objective one" (1999: 153).

For Langacker, attenuation and subjectification are gradual in nature, "involving small steps along a number of possible parameters", which include: (i) a change in status, from actual to potential, or from specific to generic; (ii) a change in focus, that is, to what extent particular elements are in focus (in profile); (iii) a shift in domain, from the domain of physical interaction to the domain of social interaction; (iv) and, a change in mover, from a specific, onstage participant, the trajector, to an offstage participant, the addressee, or some generalized mover (1999: 155f).

All in all, according to Langacker (1999), attenuation as a process of subjectification figures in many cases of grammaticization, e.g. the development of the English be going to construction (see also Evans and Green 2006: 730-733), the deontic senses of modals, the auxiliary have, among others. To quote Langacker himself: "Attenuation in subject control has been shown to be a pervasive, multifaceted phenomenon that plays a major role in certain kinds of grammaticization, with important consequences for synchronic analysis and description" (1999: 172).

For Traugott $(1989,1999,2010)$, subjectification, as well as intersubjectification, is a diachronic process of pragmatically evoked semanticization which often co-occurs with grammaticalization. In the process of subjectification, meanings are becoming increasingly associated with the speaker's beliefs and attitudes towards the proposition (see Traugott 1989: 31). Believed to be "the most pervasive tendency in semantic change" (Traugott 1999: 188), subjectification in this paradigm is considered to be a result of "pragmatic strengthening" and pragmatically triggered enrichment of old forms so that they serve to express the point of view of the speaker. When the pragmatically influenced new uses of a form become conventionalized, Traugott (1989) speaks of language change. And yet, even though in her approach subjectification is a diachronic phenomenon, it allows for variation at the synchronic level. Synchronically, structures display varying degrees of subjectification, which results in a number of their coexisting meanings (see Traugott 1999: 188).

As regards intersubjectification, Traugott conceives of it as "the development of the speaker's attention to the addressee's self-image" (2010: 60). In other words, while subjective meanings encode the perspective of the speaker and his attitude to the state of affairs in question, intersubjective meanings, over time, begin to encode the perspective of the addressee of the proposition. Crucially, intersubjectification originates in subjectification, which is illustrated by the cline below (see Traugott 2010: 35):

(1) 
In Traugott's view, although intersubjectification, just like subjectification, starts with pragmatic considerations in certain contexts, it is a process of semanticization rather than pragmatization, and takes place only once a form acquires a newly coded intersubjective meaning which becomes conventionalized. Also, like subjectification, intersubjectification involves "the reanalysis as coded meaning of pragmatic meanings arising in the context of speaker-hearer negotiation of meaning" (Traugott 2010: 60). Last but not least, intersubjectification is a diachronic process whose effects can sometimes be observed only synchronically.

Directly relevant for the present study are observations made by Company (2006: 376) who notes that subjectification has been mainly described from the semantic-pragmatic point of view, while it is equally worthwhile to look at this process from the perspective of syntax. She points out that there is an inverse correlation between the form's subjective meaning and the quantity of syntax that the form requires, that is, with the increase in subjectivity, the form becomes increasingly restricted syntactically (see Company 2006: 381-393). On the one hand, the time needed for subjectification to take place naturally implies the cancelation of syntactic form. On the other hand, the speaker concerned with projecting his judgment, evaluation, and perspective lacks interest in the referential descriptive syntactic aspects of an expression. As a result, elaborate structure becomes redundant in subjectification and subjective expressions undergo syntactic cancellation and isolation.

Drawing on her study of the phenomenon of subjectification in Spanish, Company (2006) formulates three tendencies, or factors, which she uses for the study of language change in Spanish: (i) fixation of form and autonomy of predication, (ii) fronting and widening of predicational scope, and (iii) weakening of agent control. These three factors are used in my study to account for the distribution and semantic behaviour of niestety 'unfortunately/regrettably'.

\section{The study}

\subsection{Fixation of form and autonomy of predication}

Company (2006: 381) argues that subjectification is manifested in the evolution of forms into fixed expressions, signaled by the prosodic independence of items and their syntactic isolation. Fixation of form and autonomy of predication is claimed to be an especially strong tendency in the development of evaluative discourse markers (see the discussion in Company 2006: 382).

The analysis of the corpus of niestety 'unfortunately/regrettably' in the light of this factor consisted in identifying cases in which niestety occurs with markers of prosodic independence. Specifically, the data were examined in order to identify cases in which niestety is separated from the context by commas, as in (2a), by pauses signalized by dots, as in (2b), by other punctuation marks, or in syntactic isolation ${ }^{3}$.

3 With respect to the use of markers of prosodic independence, only the immediate contexts of the sentences in which the adverb occurred, rather than whole samples, were examined. Importantly, in my count I followed the original punctuation of the samples. 
(2) (a)

[Łukasz Derbich, a footballer of Cracovia, asked in an interview about his understanding of the phrase "a set piece of a game" and explaining that it has been a serious problem for the team]

$\begin{array}{llll}\text { Niestety, } & \text { koszmar } & \text { wrócit } & i \\ \text { unfortunately/ regrettably.ADV } & \text { nightmare } & \text { is back } & \text { and }\end{array}$

tracimy bramki.

lose 2PL.PRES goals.

'Unfortunately, the nightmare is back and we are losing goals'

http://sport.interia.pl/pilka-nozna/ekstraklasa/news/derbich-niestety-koszmar -wrocil,1389131,812

(b)

[about a longing for the literature of the interwar period and lack of film adaptations of the literature of this period]

$\begin{array}{llll}\text { Dwudziestolecie... } & \text { niestety, } & \text { trzeba } & \text { czytać } \\ \text { the interwar period... } & \text { unfortunately.ADV } & \text { must.PRED } & \text { read.INF }\end{array}$

'Unfortunately, literature of the interwar period must be read'

http://stopklatka.pl/felietony/felieton.asp?f1i=200

A careful analysis of the samples reveals that in as many as 17 cases niestety occurs in the context of a comma. Moreover, three times it was used in syntactic isolation, twice in the context of pauses signalized by dots, and once with the brackets. Five more times it was used with other punctuation devices (exclamation mark and dash). All in all, the majority of samples in the collected corpus (28 in 50) are biased towards contexts indicating prosodic independence and syntactic isolation of the items, which shows that the behaviour of niestety is clearly influenced by the process of subjectification.

\subsection{Weakening of agent control}

Another factor included by Company (2006: 378) in her list of syntactic manifestations of subjectification is the degree of agent control. Langacker (1991: 285) defines the term 'agent' as "a person who volitionally initiates physical activity resulting, through physical contact, in the transfer of energy to an external object". The weakening of agent control refers to Langacker's (1999) observations that there is a preference for subjective expressions to take inanimate subjects rather than volitive agentive subjects. It is also very frequent that subjective expressions do not have a subject at all. 
In the present study, the corpus of niestety 'unfortunately/ regrettably' was examined with respect to the types of subjects featuring in the utterances with this adverb. The variety of subjects encountered is illustrated by the examples in (3)-(10) below. While as many as 3 uses of niestety in the corpus are cases with the speaker construed as the subject of a construction, there are also 5 cases in which human agent subjects were identified. In (3), the prince is apparently gone, but his act of going away and leaving behind a white horse as a consolation was volitional, and therefore, the subject is considered agentive.

(3)

$\begin{array}{lllllll}\ldots a & \text { ksiqże } & \text { niestety } & \text { uciekt } & w & \text { sinq } & \text { dal... } \\ \text {...while } & \text { prince } & \text { unfortunately.ADV } & \text { escaped } & \text { in } & \text { livid } & \text { distance... }\end{array}$

$\begin{array}{llll}\text { napocieszenie } & \text { zostawit } & \text { białego } & \text { konia } \\ \text { on consolation } & \text { left.2SG } & \text { white } & \text { horse }\end{array}$

'the prince unfortunately went away for good... leaving behind a white horse as a consolation' http://dzierzba.flog.pl/wpis/569088/a-ksiaze-niestety-uciekl-w-sina-dalnaך -pocieszenie-zostawil-bialego-konia

There are also cases in the corpus, such as (4), which posed considerable problems with their description. Although there are reasons for treating (4) as a case of the human agent subject construction, there are other reasons for seeing it as a construction with the subject in the role of the experiencer. If we look at the profiled relationship from the standpoint of absolute construal (see Langacker 1991), (4) indicates that Ewa Milewicz has been overcome by the power of a particular trend towards rejecting orders awarded by the President of Poland. Having succumbed to this trend, Ewa Milewicz codes an experiencer subject, rather than a volitive human agent subject.

(4)

[a radio interwiew with Władysław Stasiak, a minister of the former President, who talked about people who had rejected medals awarded by President Lech Kaczyński]

$\begin{array}{lllll}\text { Stasiak: } & \text { Ewa Milewicz } & \text { niestety } & \text { uległa } & \text { pewnej modzie } \\ \text { Stasiak.NOM } & \text { [Ewa Milewicz].NOM } & \text { unfortunately.ADV } & \text { succumbed.3SG } & \text { [some fashion].DAT }\end{array}$

'Stasiak: Unfortunately, Ewa Milewicz has succumbed to some trend.'

http://tok.fm/TOKFM/1,91171,6488139,Stasiak_Ewa_Milewicz_niestety_ulegla _pewnej_modzie.html 
The analysis of the corpus also revealed two uses of niestety with the inanimate mover subject, the mover understood as "an entity undergoing a change of location" (Langacker 1991: 285). In (5), such an entity is Focus, a Ford car model, and therefore, the sentence exemplifies constructions with inanimate mover subjects.

(5)

[from an automobile test report]

\begin{tabular}{|c|c|c|}
\hline $\begin{array}{l}\text { Trzy poziomy } \\
\text { three }\end{array}$ & $\begin{array}{l}\text { pracy układu } \\
\text { levels }\end{array}$ & $\begin{array}{l}\text { kierowniczego } \\
\text { [work system].GEN }\end{array}$ \\
\hline
\end{tabular}

$\begin{array}{lllll}\begin{array}{l}\text { mistrzostwo } \\ \text { mastery }\end{array} & \begin{array}{l}\text { praktyczności } \\ \text { practicality.GEN }\end{array} & \begin{array}{l}\text { to nie jest, ale } \\ \text { it not is but }\end{array} & \begin{array}{l}\text { powinno } \\ \text { should }\end{array} & \begin{array}{l}\text { wystarczyć } \\ \text { suffice.INF }\end{array} \\ \begin{array}{l}\text { Niestety, } \\ \text { unfortunately.ADV }\end{array} & \begin{array}{l}\text { Focus } \\ \text { Focus.NOM }\end{array} & \begin{array}{l}\text { jest głośny } \\ \text { is loud }\end{array} & \text { przy wyższych } & \text { by higher } \\ \text { prędkościach...... } & z & \text { powodu opływajqcego go } & \text { powietrza. } \\ \text { speeds } & \text { from } & \text { reason.GEN streamlining him } & \text { air.GEN }\end{array}$

'The steering system working on three levels is not the top of practicality but it should do. Unfortunately, the Focus gets loud at higher speed... because of streaming air' http://www.autogaleria.pl/fotografie/index_test.php?id=19845\&test=293

A substantial number of cases in the corpora of niestety 'unfortunately/regrettably' was recognized as cases with the non-human instigator subject. I use the term "instigator" in the sense of Słoń, as referring to "a causal factor that is not necessarily human" (2007: 280). Such a causal factor is grypa 'flu' as used in example (6) from the collected corpus.

(6) [about the Bird Flu virusH5N1, which, unlike in Denmark and France, did not force the Polish government to postpone the beginning of the new school year]

$\begin{array}{llllll}\text { Nowa } & \text { grypa } & \text { nie } & \text { przedłuży } & \text { (niestety) } & \text { wakacji } \\ \text { new flu } & \text { not } & \text { will } & \text { prolong } & \text { unfortunately.ADV } & \text { holidays.GEN }\end{array}$

'Unfortunately, the new flu virus will not make the holidays any longer.'

http://rynekzdrowia.pl/Choroby-zakazne/Nowa-grypa-nie-przedluzy-niestety -wakacji,9797,22.html 
Furthermore, cases of the so-called "setting-subject" were identified, with the term used in the sense of Langacker (1991: 345-348). He points out that, as long as the subject is usually considered as "the most prominent clausal participant", there are also cases in which the subject is not a participant, but an aspect of a setting. The most prototypical setting is "a spatial or temporal expanse", as in Thursday saw yet another startling development or Independence Hall has witnessed many historic events. Example (7) below illustrates uses with the spatial setting construed as the subject of the profiled relationship.

(7)

[contrasting a VW Polo GTI with a Peugeot 207 GT and a Suzuki Swift Sport]

$\begin{array}{lllll}\begin{array}{l}\text { W } \\ \text { in }\end{array} & \begin{array}{l}\text { brakuje } \\ \text { Swift }\end{array} & \begin{array}{l}\text { niestety } \\ \text { unfortunately.ADV }\end{array} & \begin{array}{l}\text { osiowej } \\ \text { axial }\end{array} & \begin{array}{l}\text { regulacji } \\ \text { regulation }\end{array} \\ \begin{array}{l}\text { kierownicy, } \\ \text { steering-wheel.GEN }\end{array} & \begin{array}{l}\text { and } \\ \text { and dzisiaj }\end{array} & \begin{array}{l}\text { feler } \\ \text { this today }\end{array} & \begin{array}{l}\text { defect } \\ \text { trudny } \\ \text { difficult }\end{array} \\ \begin{array}{l}\text { do zaakceptowania. } \\ \text { to accept }\end{array} & \text { Nie } & \text { pomaga } & \text { możliwość } & \text { zmiany } \\ & \text { not } & \text { helps } & \text { possibility } & \text { change.GEN } \\ \text { wysokości } & \text { siedzenia } & & & \\ \text { seat.GEN } & & & & \end{array}$

'The Swift unfortunately lacks the function of the steering-wheel axle adjustment and it is a defect difficult to accept nowadays. It can't be eliminated by the possibility of adjusting the height of the seat.' http://wysokieobroty.moto.pl/auto/51,71357,4056687.html?i=9

Last but not least, the corpus of niestety was examined in search of examples featuring nonspecific or generalized subjects, as well as examples with no subjects. According to Langacker, it is frequently the case in the subjective construal that the subject's role gradually decreases until, in some relationships, the subject no longer plays a role in affecting the relationship (see 1999:159162). In Langacker's words, subjects increase in non-specificity and become more and more generalized, which, taken to the extreme, qualifies as a case of 'transparency'. English examples of this tendency provided by Langacker include, among others, the so called "dummy" or "expletive" subjects, as in There is going to be another storm tonight, as well as highly grammaticized constructions in which a subject is no longer necessary at all, as in There may have been a serious breach of security, or Tabs should have been kept on all those dissidents all along (1999:160ff).

In Polish, of course, by 'no subject' we mean those constructions which are overtly impersonal. This is in contrast to those cases where subjects are left unelaborated and are not given in the 
actual sentences, which is not only frequent, but also symptomatic of both colloquial and formal Polish. Due to the inflectional character of the Polish language, such subjects are easily identifiable. An illustration of a no subject construction from the corpus of niestety is given in (8), with the non-inflectional verb trzeba. Other constructions classified as 'no subject' constructions include passive voice constructions, as well as the 3rd SG NEUTR construction, which, according to Słoń (2007: 263) is characterized by obligatory non-elaboration of the inanimate instigator-agent.

(8)

[an excerpt from a column; the author, fed up with the anniversary-like repertoire of patriotic songs on the radio, films like Black Cross, Memoirs of a Geisha, and Harry Potter and tiresome discussions on television, longs for the literature of the Interwar Period]

$\begin{array}{llll}\text { Dwudziestolecie... } & \text { niestety, } & \text { trzeba } & \text { czytać } \\ \text { the.interwar.period } & \text { unfortunately.ADV } & \text { must.IMPS } & \text { read.INF }\end{array}$

'Literature of the Interwar Period must be read ... unfortunately'

http://stopklatka.pl/felietony/felieton.asp?f1i=200

In the study, non-specific subjects were identified in cases such as (9), where it is impossible to pin down the precise referent of to 'it' in the verbless sentence Niestety, to juz koniec wakacji.

(9) [from an article; about children for whom it is hard to accept the news that the holidays are over]

$\begin{array}{lllll}\text { NIESTETY, } & \text { TO } & \text { JUŻ } & \text { KONIEC } & \text { WAKACJI } \\ \text { unfortunately.ADV } & \text { it } & \text { already } & \text { end } & \text { holidays.GEN }\end{array}$

'Unfortunately the holidays are drawing to an end'

http://sp-siercza.pl/koniec-wakacji.html

The case of the 2nd SG impersonal construction in (10) is considered as having a generalized subject. Although the notion of the addressee is evoked, the subject of the profiled relationship is non-specific. In this particular context, the message accompanying the picture has no particular addressee but it is directed at a larger group of Internauts visiting the website. 
(10)

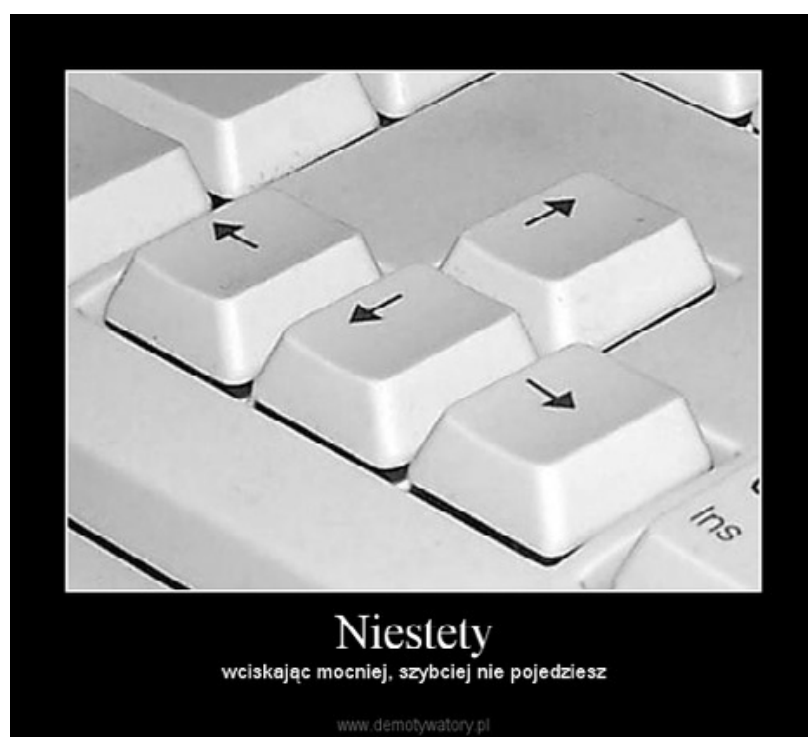

$\begin{array}{lll}\begin{array}{l}\text { Niestety, } \\ \text { unfortunately.ADV }\end{array} & \text { wciskając } & \text { mocniej } \\ & \text { pressing.PCON.IMPERF } & \text { stronger } \\ \text { szybciej, } & \text { nie } & \text { pojedziesz } \\ \text { faster } & \text { not } & \text { will.go.2SG.FIN.PERF }\end{array}$

'Unfortunately, by pressing stronger, you won't go faster.'

http://demotywatory.pl/135109/Niestety/

The analysis of the corpus samples with niestety 'unfortunately/ regrettably' in the light of the factor of weakening of agent control leads to a number of observations. There are only 5 uses of the adverb with the subject in the role of a human agent, while the adverb is strongly biased towards types of construal low in agentivity. The corpus includes 3 constructions with non-specific subjects, 4 constructions with generalized subjects, and 9 constructions with no subjects. Interestingly, niestety appears to be considerably influenced by the attenuation factor in view of the number of its uses with non-human instigator subjects and setting subjects: 13 and 10 such uses respectively.

\subsection{Fronting and widening of predicational scope}

The third factor employed in the study is fronting and widening of predicational scope. Company observes that, in spite of their flexibility with regard to their position in the discourse, subjectified expressions tend to appear at the beginning of the utterance, while in some languages they also have a tendency to appear in the rightmost position (see 2006: 378f, see also Traugott 2012). In the case of adverbs, fronting tendencies result in the widening of their scope, from over the word, or word-phrase, to sentential scope.

In Traugott's approach, adverbs are classified into three types with respect to their position in the discourse and the structural path of change: Verb Adverbs (VAdv), Sentence, or Inflectional Phase, 
Adverbs (SAdv) ${ }^{4}$, and Discourse Markers (DM). VAdv typically occurs at the end of a clause, is often an adverb of manner, and has a clause-internal scope (see 1999: 177). According to Traugott, the category is elsewhere described as adverbs of direction, manner, etc. SAdv may occur "after Complementizer or adjacent to the tensed verb" and its scope is over the clause (1999: 180). Finally, the position of DM is outside Complementizer while its scope is over the following complex structure.

According to Traugott, the process of subjectification underlies the development of adverbials in English, from VAdvs being the least subjective, via SAdvs, to the most subjective DMs. While VAdv modifies the event, SAdv modifies the clause and DM modifies the "relationship between successive discourse units" (Traugott 1999: 189). Nevertheless, as Traugott (1999: 180) argues, SAdvs and DMs need to be additionally distinguished on the basis of pragmatic differences between them rather than on the basis of their syntactic behavior only. She observes that the use of adverbs, especially of the SAdv type, is influenced by the strategy of "counter-expectation" understood as: "the speaker's expression of belief or point of view contrary to his/her own or their interlocutor's expectations concerning the state of affairs in question" (Traugott 1999: 178). Additionally, counter-expectation is very often redundantly marked in those uses, for example by modals or adversatives like although (ibid.).

As far as DMs are concerned, Traugott follows Fraser (1988: 21f) in assuming them to "signal a comment specifying the type of sequential discourse relationship that holds between the current utterance... and the prior discourse” (1999: 181). Also, using Dancygier's terminology (1992, after Traugott 1999: 181), she views them as "metatextual" devices whose function is to indicate the speaker's attitude to the text being constructed as well as to draw hearers' attention to this attitude.

In order to apply the factor of fronting and widening of predicational scope in the study of niestety 'unfortunately/ regrettably', its corpus was examined with respect to the occurrences of the adverb in question in various positions in the sentence. Importantly, there were no verb modifier uses in the corpus, even though it is the most prototypical adverb position. At the same time, as many as 26 uses are uses in the role of SAdv, which is illustrated by example (11):

[about the Bird Flu virusH5N1, which, unlike in Denmark and France, did not force the Polish government to postpone the beginning of the new school year]

$\begin{array}{llllll}\text { Nowa } & \text { grypa } & \text { nie } & \text { przedłuży } & \text { (niestety) } & \text { wakacji } \\ \text { new } & \text { flu } & \text { not } & \text { prolong.FUT } & \text { unfortunately.ADV } & \text { holidays.GEN }\end{array}$

'Unfortunately, the new flu virus will not make the holidays any longer.'

4 Traugott (1999) herself uses the term Inflectional Phase Adverb (IPAdv) to refer to adverbs in this function. In my work, I choose to use the term Sentence Adverb (SAdv), more universally used in literature (see Hoye 1997), to refer to these adverbs. 
http://rynekzdrowia.pl/Choroby-zakazne/Nowa-grypa-nie-przedluzy-niestety -wakacji,9797,22.html

Niestety in (11) is regarded as a SAdv on the grounds of its distribution after the Complementizer. It has to be noted, however, that according to Traugott, apart from their typical distribution, SAdvs additionally exhibit the characteristics of "counter-expectation" (1999: 177f). Drawing on her analysis of in fact she observes that speakers often "set up false scenarios and then show that the assumptions manifest in them are wrong and inappropriate to the occasion" (ibid.). It seems that the same strategy can be traced in the SAdv uses of niestety. Upon a closer look, the speaker in (11), presumably assuming the children's viewpoint, sets up a hypothetical scenario according to which Polish authorities decide to postpone the beginning of the school year because of the Bird Flu virusH5N1, as was the case in some other countries. Once such a scenario is created, the speaker expresses his/ her regret that it is not going to happen.

It can also be the case that the interpretation of a given message is a result of the clash between the actual state of affairs and the expected norm, as in example (12) from the collected corpus. According to the speaker, these days we usually receive a warranty for a new car that we buy from a dealer. However, in the case of second-hand vehicles, we can only get a warranty for some of their spare parts. And what is more, garages do not have to provide a warranty for their services at all. Clearly, the speaker is dissatisfied with this state of affairs, and he/ she would rather expect to receive a certified warranty for the services that he/she is paying for.

[from a press article; the author is complaining about the fact that, while car dealers give a warranty for new cars, and a limited warranty for second-hand cars, garages are not obliged to give a warranty for their services]

$\begin{array}{lllll}\text { Gwarancja } & \text { na usługe? } & \text { Niestety, } & \text { nie } & \text { zawsze. } \\ \text { warranty } & \text { on service.ACC } & \text { unfortunately.ADV } & \text { not } & \text { always }\end{array}$

'Service warranty? Unfortunately, not always'.

http://dziennik.pl/auto/article39415/Gwarancja_na_usluge_Niestety_nie_zawsze .html

As for Discourse Markers (DMs), like in the case of SAdvs, they can be differentiated on the basis of their syntactic behaviour. It is the distribution of niestety in (13) that qualifies it as a DM, in line with Traugott who claims that DMs are syntactically restricted to positions outside complementizer (1999: 177-184). At the same time, they are metatextual devices to express speakers' attitudes toward both the current and the prior discourse. Additionally, adverbs in this position signal a degree of contrast and often elaborate and clarify the ideas from the preceding context. 
Traugott believes that the strategy of counter-expectation is much weaker in the case of DMs than in the case of SAdv, but it can nevertheless be traced. This contrast typical of DMs, as well as the clarification of the prior discourse, seems apparent in (13), as the adverb evokes a negative meaning itself. The idyllic picture of the Baltic seaside that is like the Riviera is quickly shattered at the mention of the climate changes that are to bring adverse and inevitable effects.

(13)

\begin{tabular}{|c|c|c|c|c|c|c|}
\hline Riwiera & nad & Bałtykiem & \multicolumn{2}{|l|}{$i$} & słodkie & wina \\
\hline Riviera & at & the Baltic & \multicolumn{2}{|l|}{ and } & sweet & wines \\
\hline$z$ & polskich & winnic? & \multicolumn{2}{|c|}{ Niestety, } & zmiany & klimatu \\
\hline from & Polish & vineyards & \multicolumn{2}{|c|}{ unfortunately.ADV } & changes & climate.GEN \\
\hline będa & miały & cierpki & smak. & Jeśli & sqqdzisz, że & zmiany \\
\hline will & have & tart & taste & if & think.2SG & that changes \\
\hline klimatu & będa & dla nas & dobre, & nowy & raport & Banku \\
\hline climate.GEN & will.be & for us & good & new & report & Bank.GEN \\
\hline Światowego & wyprowadzi & & cię & $z$ & błędu. & \\
\hline World.ADJ & lead.out.3SG.FUT & & & from & mistake & \\
\hline
\end{tabular}

'The Riviera at the Baltic Sea and sweet wines from Polish vineyards? Unfortunately, the climate changes will taste tart. If you think that the climate changes will be good for us, the new report of the World Bank will show that you are mistaken.'

http://dlaklimatu.pl/Riwiera-nad-Baltykiem-i-slodkie

The message conveyed in example (5) quoted in Section 4.2 is similar. The Focus is reported to be equipped with some technical solutions that should satisfy the potential customers. And yet, as the author of the car review points out, it is not free of drawbacks such as being loud at higher speed.

Apart from the sentence-initial position in which adverbs like niestety 'unfortunately/regrettably' are used in Polish, they are likely to appear in the rightmost position; there are 4 such instances in the present corpus. Niestety in this position is an after-comment to the preceding discourse, as in example (14). Often, the adverb is an additional comment, contrastive to what may normally be expected. Clearly, the adverb in this position has a sentential scope.

5 This is also observed in Spanish (see Company 2006). 
(14)

[about Bartłomiej Adamczuk's diploma design of a new Widzew stadium]

$\begin{array}{llllll}\text { Kibice } & \text { Widzewa } & \text { mogq } & \text { o } & \text { takim pomarzyć. } \\ \text { supporters } & \text { Widzew.GEN } & \text { can.PL.PRES } & \text { of } & \text { such } & \text { dream.INF }\end{array}$

\section{Niestety}

unfortunately.ADV

'The supporters of Widzew can only dream of such a stadium. Unfortunately.'

http://stadiony.net/news.php?n=1446

\section{Marker of intersubjectivity}

There is one corpus example, here given in (15), which does not fall in any of the categories described in the previous section. In this example, niestety stands alone and is both the title of a photograph and a comment on the state of affairs depicted in the photo, undoubtedly expressing the attitude of the speaker towards this state of affairs.

(15)

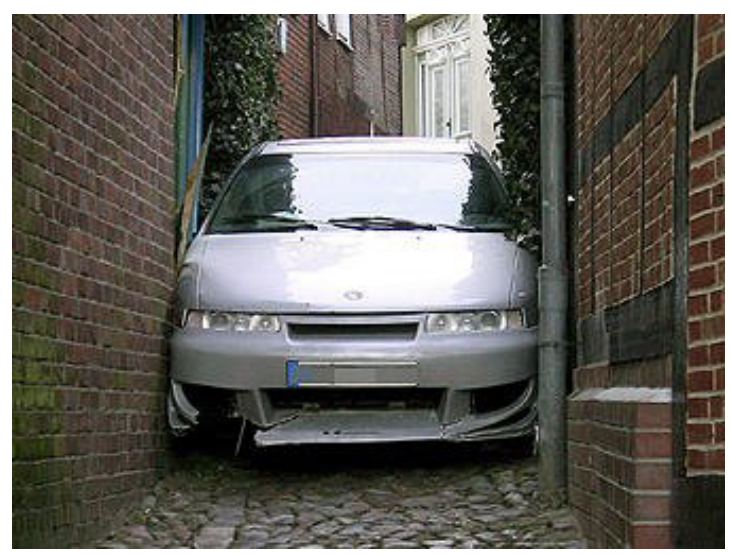

niestety

unfortunately.ADV

'Unfortunately'

http://patrz.pl/zdjecia/niestety

Upon a closer look, niestety in (15) is prone to be interpreted as expressing ridicule and contempt of the speaker for the driver of the car. It is not difficult to arrive at these interpretations even though no linguistic context is provided apart from niestety.

The question can be posed of how it is possible that a speaker who ridicules and negatively assesses the lack of imagination of the driver of the car in the photo uses the adverb niestety 'unfor- 
tunately/regrettably' to express his attitude. The state of affairs in question can be found unfortunate only if the speaker assumes the perspective of the owner of the car. The owner, or the driver of the car, may be considered a potential hearer, whereas assuming his/her perspective results in an intersubjective reading, even if only to create a pun. The intersubjectivity of this particular case is contextually driven (see Section 2), the context being the photograph itself.

A clearer case of an intersubjectified use of niestety is example (16) in which the speaker, apparently glad that he/she is right, says niestety as if on behalf of the addressee. This in itself illustrates the process of intersubjectification, as described by Traugott (2010; see Section 3).

$\begin{array}{llll}\text { Niestety } & \text { (ale) } & \text { mam } & \text { rację. } \\ \text { unfortunately.ADV } & \text { (but) } & \text { have.1SG.PRES } & \text { rightness.ACC }\end{array}$

'Unfortunately, I'm right.'

Although (16) is a constructed example, Polish allows for such uses. Consider the words of Witold Waszczykowski, Polish Minister of Foreign Affairs, quoted in wpolityce.pl. Schetyna is the leader of the biggest opposition party in Poland nowadays. They call themselves "total opposition". In view of this, it is impossible to assume that Waszczykowski regrets that Schetyna is not telling the truth. Quite the opposite, niestety in this utterance only makes sense if we assume the perspective of Schetyna himself and other members of the opposition party.

[part of an interview with Minister of Foreign Affairs, Witold Waszczykowski, in which he denied the words of Grzegorz Schetyna about Barack Obama rejecting the proposal of meeting President Andrzej Duda; he explains that no such meeting was being planned in the first place]

$\begin{array}{llll}\begin{array}{l}\text { No } \\ \text { Well }\end{array} & \begin{array}{l}\text { niestety, } \\ \text { unfortunately.ADV }\end{array} & \begin{array}{l}\text { muszę } \\ \text { must.1SG }\end{array} & \begin{array}{l}\text { powiedzieć } \\ \text { say }\end{array} \\ \text { że } & \text { pan Schetyna } & \text { kłamie. } & \\ \text { that } & \text { Mr Schetyna } & \text { is lying. }\end{array}$

'Well, unfortunately, I have to say that Mr Schetyna is lying.'

http://wpolityce.pl/polityka/286855-waszczykowski-niestety-musze-powiedziec-ze

-pan-schetyna-klamie-prezydent-obama-nie-odmowil-zadnego-spotkania

Some usages of niestety 'unfortunately/regrettably' in Polish may suggest that speakers are aware that they do not speak on their own behalf. You sometimes hear Polish speakers say a non- 
existent word stety 'fortunately' in order to, as if, correct themselves right after they use niestety. It seems that this need of self-correction arises when speakers realize that the niestety that they say does not express their own point of view but somebody else's. This is the case in (18) where niestety may be associated with the point of view of either all the citizens of the European Union, or those citizens who support the idea of the EU.

[Tomasz Kalinowski, the Press Secretary of ONR, for Republika TV (2nd May 2017)]

$\begin{array}{llll}\begin{array}{l}\text { Unia Europejska } \\ \text { European Union }\end{array} & \begin{array}{l}\text { będzie } \\ \text { will.be }\end{array} & \begin{array}{l}\text { niestety, } \\ \text { unfortunately.ADV }\end{array} & \begin{array}{l}\text { znaczy } \\ \text { mean.3SG.PRES }\end{array} \\ \text { *stety, } & \text { odchodziła } & \text { do } & \text { lamusa. } \\ { }^{*} \text { fortunately } & \text { go.35G.FEM.PRES } & \text { to } & \text { junk.room.GEN }\end{array}$

'The European Union will be, unfortunately- I mean, fortunately- going out of date.'

The two uses of niestety in (19) below are quoted after Miodek (2000), who considers these sentences as ill-formed, which, as he explains, is a result of the users of Polish becoming less and less sensitive to the semantic values of the words they use these days.

(19) (a)

$\begin{array}{llll}\begin{array}{l}\text { Kiedy } \\ \text { when }\end{array} & \begin{array}{l}\text { widzi } \\ \text { see.3sG }\end{array} & \begin{array}{l}\text { policjanta, } \\ \text { policeman }\end{array} & \begin{array}{l}\text { niestety } \\ \text { unfortunately.ADV }\end{array} \\ \text { zdejmuje } & \text { noge } & z & \text { gazu. } \\ \text { remove.3SG } & \text { leg.Acc } & \text { from } & \text { accelerator.GEN }\end{array}$

'When he sees a policeman, he unfortunately takes his foot off the accelerator.'

(b)

$\begin{array}{llll}\begin{array}{l}\text { Niestety, } \\ \text { unfortunately.ADV }\end{array} & \begin{array}{l}\text { już } \\ \text { already }\end{array} & \begin{array}{l}\text { jesteś } \\ \text { are.2SG }\end{array} & \begin{array}{l}\text { zdrów, } \\ \text { healthy }\end{array} \\ \text { jutro } & \text { idziesz } & \text { do } & \text { szkoły. } \\ \text { tomorrow } & \text { go.2SG } & \text { to } & \text { school }\end{array}$

'Unfortunately, you are no longer sick. You are going to school tomorrow.' 
According to Miodek, the words of a policeman in (19a) only make sense if we assume that the policeman finds it unfortunate that he misses a chance to give the driver a ticket for exceeding the speed limit. In (19b), Miodek points out that it was actually a happy mother whom he heard uttering these words. In both cases, we need to reconsider the described state of affairs from a perspective other than that of the speaker, the perspective of the addressee in case (19b), and only then the use of niestety seems justified.

Examples (16)-(17), and probably (19), should be regarded as cases of intersubjectification, in line with Traugott (2010), for whom it naturally emerges from subjectification (see the discussion in Section 3). At the same time, the fact that such uses of niestety are not necessarily attested in standard Polish may suggest that their intersubjectification is pragmatically inferential and not conventionalized, and therefore it is not a case of semanticization.

The corpus of niestety 'unfortunately/regrettably' in the present study clearly contains cases indicating the process of intersubjectification. Most frequently, intersubjective readings were identified in the context of first persons plural, as example (20) illustrates.

(20)

$\begin{array}{llll}\begin{array}{l}\text { Nasze } \\ \text { our }\end{array} & \begin{array}{l}\text { długi, } \\ \text { debts }\end{array} & \begin{array}{l}\text { niestety } \\ \text { unfortunately.ADV }\end{array} & \begin{array}{l}\text { rosnq. } \\ \text { grow }\end{array} \\ \begin{array}{l}\text { Coraz } \\ \text { more.and.more }\end{array} & \begin{array}{l}\text { difficult Poles.DAT } \\ \text { pay }\end{array} & \text { their } & \\ \text { zadłużenie } & \text { wobec } & \text { banków, } & \text { zakładów energetycznych, } \\ \text { debt } & \text { to } & \text { banks.GEN } & \text { electricity boards.GEN }\end{array}$

spółdzielnimieszkaniowych czy firm telekomunikacyjnych.

housing associations. GEN or telecommunications companies. GEN

'Our debts are unfortunately growing. It is becoming more and more difficult for Poles to pay their debts to the banks, electricity boards, housing associations, or telecommunications companies.'

http://mkredyty.net/wiadomosci/banki/nasze-dlugi-niestety-rosna

Nasze długi 'our debts' and niestety 'unfortunately/regrettably' in the first sentence in (20) signal the attitude of the speaker toward a state of affairs: while it is open to question whether the speaker is indebted himself/herself, he/she talks about the indebtedness of the community that he/she is a member of with sympathy. The intersubjective reading becomes more evident in the context of the second utterance, where the speaker speaks of the Polish who find it more and more difficult to pay their debts these days. Niestety expresses an evaluation of the state of affairs in question not 
only from the speaker's own perspective, but also from the perspective of the addressee who, just like him/her, belongs to the community of Polish people.

In the analyzed corpora, it is possible to identify about 15 cases of intersubjective uses of niestety. ${ }^{6}$ Apparently, niestety 'unfortunately/regrettably' can undergo the process of intersubjectification. However, the uses in the corpus of this study suggest that intersubjective interpretations of the adverb are contextually driven, rather than a result of the fully-fledged subjectification. At the same time, the research method applied does not allow the identification of cases of extreme intersubjectification leading to semanticization (see the discussion in Section 3).

\section{Summary}

The article presented the results of an analysis of the adverb niestety 'unfortunately/regrettably' conducted on the corpus data which secured a high representativeness of the samples with respect to the styles and registers in which the adverb was used. The three factors employed in the study, proposed by Company (2006) and used by her in the study of Spanish adverbs, proved to be reliable tools for the examination of the processes underlying the development of subjective and intersubjective senses of niestety. The analysis of the corpus data has led to a number of conclusions:

1. The samples reveal that the subjectification and intersubjectification of niestety 'unfortunately/regrettably' is manifested in the occurrence of the adverb in contexts indicating prosodic independence and syntactic isolation.

2. In view of the factor of weakening of agent control, niestety shows a strong bias towards types of construal low in agentivity. While the adverb can be used, for instance, with human subjects, such uses are scarce. At the same time, niestety most frequently appears with non-agentive and diffuse subjects. In this way, the subjectification of niestety can be traced on the synchronic level, which is in line with Langacker's (1999) claims that attenuation in subject control is a phenomenon relevant for the study of grammaticalization.

3. The uses of niestety as SAdv and DM are constrained syntactically as well as pragmatically. Traugott's observations concerning the influence of the strategy of counter-expectation on the development of SAdv and DM uses of in fact can be successfully extended to account for the development of niestety in Polish.

4. Moreover, niestety is frequently used as a marker of intersubjectivity, which emerges naturally from its subjectified senses. The corpus uses suggest, however, that the intersubjective interpretations of the adverb are contextually driven, rather than a result of a fully-fledged subjectification, whereas the method applied in the study does not allow the identification of cases of extreme subjectification leading to semanticization. All things considered, niestety 'unfortunately/regrettably' always expresses the degree of the speaker's emotional 
assessment of the state of affairs in question, while its different senses are indicative of pragmatic polysemy (Traugott 1999: 180). ${ }^{7}$

5. The case of niestety shows that together with its increase in subjectification, the adverb is becoming restricted syntactically to positions enhancing its propositional scope. The samples indicate the gradualness of the process of subjectification. As Traugott claims, subjectification, being mainly diachronic in nature, on the synchronic level may result in "layerings of less or more subjective meanings for the same lexical item or construction” (1999: 188).

\section{References}

Bańkowski, Andrzej. 2000. Etymologiczny słownik języka polskiego. Warszawa: PWN.

Company, Company Concepción. 2006. Zero in syntax, ten in pragmatics: Subjectification as syntactic cancellation. In: Athanasiadou, Angeliki, Canakis Costas and Bert Cornillie (eds.), Subjectification. Various Paths to Subjectivity, 375-397. Berlin/New York: Mouton de Gruyter.

de Haan, Ferdinand. 2006. Typological approaches to modality. In: Frawley, William (ed.), The Expression of Modality, 27-69. Berlin/New York: Mouton de Gruyter.

Dancygier, Barbara. 1992. Two metatextual operators: Negation and conditionality in English and Polish. Proceedings from the 18th Annual Meeting of the Berkeley Linguistics Society, 61-75.

Evans, Vyvyan and Melanie Green. 2006. Cognitive Linguistics: An Introduction. Edinburgh: Edinburgh University Press.

Fraser, Bruce. 1988. Types of English discourse markers. Acta Linguistica Hungarica 38, 19-33.

Grzegorczykowa, Renata. 2008. Wykłady z polskiej składni. Warszawa: PWN.

Hoye, Leo. 1997. Adverbs and Modality in English. London/New York: Longman.

Kozarzewska, Emilia. 1990. Czasowniki mówienia we współczesnym języku polskim. Studium semantyczno-składniowe. Warszawa: Wydawnictwa Uniwersytetu Warszawskiego.

Krzyżanowski, Piotr. 1992. Fleksja rzeczownika jako środek wyrażania wartości w języku polskim. In: Falkenberg, Gabriel, Fries Norbert and Jadwiga Puzynina (eds.), Wartościowanie w języku i tekście, na materiale polskim i niemieckim, 279- 284. Warszawa: Wydawnictwa Uniwersytetu Warszawskiego.

Langacker, Ronald W. 1989. Subjectification. Duisburg: L.A.U.D.

Langacker, Ronald W. 1991. Foundations of Cognitive Grammar. Vol. 2. Descriptive Application. Stanford: Stanford University Press.

Langacker, Ronald W. 1999. Losing control: grammaticization, subjectification, and transparency. In: Blank, Andreas and Peter Koch (eds.), Historical Semantics and Cognition, 147-175. Berlin/ New York: Mouton de Gruyter.

7 Traugott assumes that polysemy may be both semantic and pragmatic. Consequently, she regards the distinctions between SAdvs and DMs uses of in fact as polysemous. 
Milewska, Małgorzata. 2003. Rzeczowniki ekspresywne na -isko w języku polskim i górnołużyckim. In: Pstryga, Alicja (ed.), Wokół struktury słowa, 63-71. Gdańsk: Wydawnictwa Uniwersytetu Gdańskiego.

Miodek, Jan. 2000. Rozmyślajcie nad mową - niestety. Wiedza i Życie 2. http://archiwum.wizך .pl/2000/00021100.asp (22 October 2009).

Nuyts, Jan. 1994. Epistemic Modal Qualifications: On their linguistic and conceptual structure. Antwerp Papers in Linguistics 81.

Nuyts, Jan. 2005. The modal confusion: on terminology and concepts behind it. In: Klinge, Alex and Henrik Høeg Müller (eds.), Modality: Studies in form and function, 1-38. London: Equinox.

Nuyts, Jan. 2006. Modality: Overview and linguistic issues. In: Frawley, William (ed.), The Expression of Modality, 1-26. Berlin/New York: Mouton de Gruyter.

Piórkowska, Agnieszka. 2011. On the Margins of the Modality Category: The case of boulomaic modality. A cognitive study. Unpublished PhD dissertation, University of Warsaw.

Rybarczyk, Magdalena. 2015. Demonstratives and Possessives with Attitude. An Intersubjectively-Oriented Empirical Study. Amsterdam/Philadelphia: John Benjamins Publishing Company.

Słoń, Anna. 2007. The 'impersonal' impersonal construction in Polish. In: Divjak, Dagmar and Agata Kochańska (eds.), Cognitive Paths into the Slavic Domain, 257-287. Berlin/New York: Mouton de Gruyter.

Szymanek, Bogdan. 2010. A Panorama of Polish Word-Formation. Lublin: Wydawnictwo KUL.

Traugott, Elizabeth C. 1989. On the rise of epistemic meanings in English: an example of subjectification in semantic change. Language 65(1), 31-55.

Traugott, Elizabeth C. 1999. The rhetoric of counter-expectation in semantic change: A study in subjectification. In: Blank, Andreas and Peter Koch (eds.), Historical Semantics and Cognition, 177-196. Berlin/New York: Mouton de Gruyter.

Traugott, Elizabeth C. 2010. (Inter)subjectivity and (inter)subjectification: A reassessment. In: Davidse, Kristin, Vandelanotte Lieven and Hubert Cuyckens (eds.), Subjectification, Intesubjectification, and Grammaticalization, 29-74. Berlin/New York: Mouton de Gruyter.

Traugott, Elizabeth C. 2012. Intersubjectification and clause periphery. English Text Construction 5(1), 7-28.

Taylor, John E. and Kam-Yiu S. Pang. 2008. Seeing as though. English Language and Linguistics 12(1), 103-139. 